\title{
The Effect of IFRS Convergence and the Proportion of Woman in Audit Committee on Earning Management
}

\author{
Dwi Surti Siswanti ${ }^{1}$, and Ataina Hudayati ${ }^{1}{ }^{*}$ \\ ${ }^{1}$ Accounting Department, Economics Faculty, Universitas Islam Indonesia, Yogyakarta, Indonesia
}

\begin{abstract}
This study aims to find empirical evidence the effect of IFRS convergence and the proportion of woman in audit committee on earning management. Respondents used in this study were companies listed in Jakarta Stock Exchange for the year 2011 until 2013. Using moderated regression analysis this study supports the hypothesis that IFRS convergence and the proportion of woman in audit committee have negative effect on earning management. This finding implies that IFRS convergence and the proportion of woman in audit committee will increase the quality of financial reporting.
\end{abstract}

\section{Background of the study}

In this globalization era, standardization and harmonization of accounting standards is a necessity that can not be postponed again. Therefore, convergence on International Financial Reporting Standards (IFRS) that has been done in Indonesia and abroad is accordance with the needs of business practitioners. Some authors argue that there are many benefits of IFRS one of which is that IFRS is likely to reduce earnings management. Researches linking the convergence of IFRS and earnings management include [1]; [2]; [3] and [4].

In Indonesia, studies linking the convergence of IFRS with earnings management have also been made include [5]; [6];[7];[8]and[9]. The results of research showing the relationship between IFRS convergence conducted in foreign countries and in Indonesia is inconsistent and therefore opening space for doing similar research. Therefore the aim of this paper was to examine the effect of the convergence of IFRS with earnings management. In addition, this study also adds a variable that can reduce the likelihood of earnings management that has not been examined in previous studies i.e. the effect of the proportion of women members in audit committee on earning management.

\footnotetext{
*Corresponding author:ahudayati@yahoo.com
} 


\section{Theoretical bases}

Agency theory explains the problems that occur between the agent and the principal, where the agency problem arises because the agent has a tendency to pay attention to their own interests that do not always correspond with the principal interest[10]. In the field of financial accounting, agency theory argues that the function of financial reporting is to reduce agency problem between the company and shareholders. This argument implies that IFRS is expected to reduce the negative behavior of the managers by publishing good quality of financial reporting.

This paper use three variables i.e. IFRS convergence, the proportion of women members in audit committee and earning management. According to "Indonesian Dictionary" (http://kbbi.web.id/) convergence means "the state toward a rendezvous point". As such, the IFRS convergence is often defined as a process that aims to establish the accounting standards that can be applied worldwide. Earnings management is defined as managers use judgment in preparing financial reporting by allowing the financial reporting so that the financial statements be biased (misleading) or manager affects various contracts using accounting numbers [11].

\section{Hypothesis developments}

\subsection{Effect of IFRS convergence on earnings management}

Some previous studies support the agency theory which states that IFRS may reduce earning management. Some authors which found that IFRS convergence is an effective tool to reduce earnings management include[1]; [12];[13]and[4]. Study in Indonesia found empirical evidence that there was a negative relationship between IFRS convergence and earnings management was [5]. Thus it can be formulated hypothesis 1 of this study: H1: IFRS convergence has a negative impact on earnings management.

\subsection{Effect of the proportion of women members in audit committee on earning management}

Some preliminary research shows that women in board of director has a role to lower earnings management, namely [14]; [15]; and [16]. Research carried out in Indonesia that show the effectiveness of the audit committee to lower earnings management, namely [17]. Various research which demonstrate the contribution of women in the board of directors include [18]; [19]; [20] and[21] seems to be used to predict the influence of women on the performance of the audit committee. Formally, the second hypothesis in the study can be formulated as follows:

$\mathrm{H} 2$ : Proportion of women members in audit committee negatively affects earnings management.

\subsection{Proportion of woman members in audit committee strengthening the relationship between IFRS convergence and earnings management}

According to [22], the audit committee is moderating variables on the relationship between tenure and reputable public accounting firms to audit quality. [9], found empirical evidence that the characteristics of the audit committee in the form of financial and accounting expertise moderate the relationship between IFRS convergence and earnings management. Furthermore,[5]also examine the influence of corporate governance (managerial ownership) 
as the moderating variable on the relationship between convergence of IFRS and earnings management. Nevertheless, the results of the study cannot prove the hypothesis.

Unlike the two studies conducted in Indonesia, a study done in France [4] found that corporate governance (composed of independence of the board of directors, independence of audit committees, as well as the quality of external audits) reinforce the effect of IFRS convergence in reducing earnings management. Therefore, the third hypothesis of this study was formulated as follows:

H3: Proportion of woman members in audit committee strengthening the relationship between IFRS convergence and earnings management.

\section{Population and research sampling}

The populations in this study are all manufacturing companies whose shares are listed on the Indonesia Stock Exchange from 2011 until 2013. The elections of the year used in this study (2011-2013) because (2008-2012) is the first phase of IFRS convergence, i.e., while the year 2013 is the second phase of IFRS convergence.

\section{Variable definition and measurement}

The dependent variable used in this study is the earning management. Earnings management is defined as "managers use judgment in preparing financial reporting by allowing the financial reporting so that the financial statements be biased (misleading) or manager affects various contracts relating to itself using accounting numbers [11]. In this study, the earnings management measured by discretionary accruals which is calculated using the modified Jones model.

The independent variable used this study were the convergence of IFRS and the proportion of woman in audit committee. Convergence to IFRS can be interpreted to make the same accounting standards of a country with IFRS. IFRS Convergence measured using dummy variables to measure when companies converge IFRS rated 1 if it does not converge IFRS rated 0 [12].The proportion of women in audit committee is a comparison between the number of women in audit committee divided by the total members of audit committee [23] and [4].

\section{Results}

Moderating regression analysis in this study can be seen in table 1 below:

Table 1 Regression Analysis

\begin{tabular}{|l|r|r|r|r|}
\hline & \multicolumn{2}{|c|}{ Coefficients } & \multicolumn{1}{c|}{ T } & \multirow{2}{*}{ Sig. } \\
\cline { 2 - 3 } & \multicolumn{1}{|c|}{ B } & \multicolumn{1}{c|}{ Std. Error } & & \\
\hline Constanta &, 273 &, 191 & 1,427 &, 158 \\
IFRS &,- 222 &, 100 & $-2,210$ &, 030 \\
Woman & $-1,160$ &, 288 & $-4,022$ &, 000 \\
Audit & & & & \\
Committee & & & & \\
IFRS*WAC &, 632 &, 288 & 2,192 &, 031 \\
\hline
\end{tabular}

Analysis found that coefficient of determination (Adjusted $\mathrm{R}^{2}$ ) was 0.213 . These results can be concluded that the variations of dependent variable affected by independent variable 
were $21.3 \%$ and the remaining $78.7 \%$ was influenced by other factors not included in the regression model. $\mathrm{F}$ test also found significant of $\mathrm{F}$ value, then it shows that the regression model can be used to predict the research model.

The first hypothesis stated that the convergence of IFRS has a negative effect on earnings management. Regression coefficient of IFRS convergence was -0.222 and $p$ value was 0,030 . which means convergence of IFRS has a negative effect on earnings management. It can be concluded that the first hypothesis of this study was supported.

The second hypothesis of this study states that the proportion of woman in audit committee negatively affect earnings management. The magnitude of the regression coefficient of the proportion of women in audit committee was -1.160 and $p$ value was 0.000 , which means the proportion of woman in audit committee negatively affect earnings management so it can be concluded that the second hypothesis was supported.

The third hypothesis of this study stated that the proportion of the woman in audit committee reinforce negative relationship between the convergence of IFRS on earnings management. The amount of interaction regression coefficient was 0.632 and $p$ value 0.031 . From the analysis it can be concluded that although the interaction between the proportion of women in the audit committee and the convergence of IFRS have significant influence on earnings management, but the direction of the relationship indicates the opposite of that predicted. It can be concluded that the third hypothesis was not supported.

\section{Discussions}

This study aimed to analyze the relationship between the IFRS convergence and the proportion of women members in audit committee on earnings management. Preliminary research indicates that the interaction between the IFRS convergence and corporate governance can reduce earnings management. These studies expand the preliminary study on the role of corporate governance in reducing earnings management.

The results of this study prove that the convergence of IFRS has a significant negative effect on earnings management. Thus, this study supports the agency theory that IFRS has a monitoring tool that can reduce earnings management. The findings of this study are consistent with previous studies that examined the relationship between the convergence of IFRS and earnings management[1]; [4];[24];[5].

The results of this study demonstrate that the proportion of woman in audit committee has significant negative effect on earnings management. In addition to supporting the agency theory, this findings also supports the prediction of stakeholder theory. Stakeholder theory predicts women's leadership is seen as more concerned with the interests of more stakeholders than man's leadership.

The results of this study prove that the woman in audit committe strengthen the positive relationship between the convergence of IFRS on earnings management. The results of this study indicate that the interaction between convergence of IFRS and the audit committee will boost earnings management. In other words, the presence of both these monitoring mechanisms (internal and external mechanisms) at the same time will negatively impact on the quality of financial reporting by increasing earnings management. So that the findings of this study are not consistent with the hypothesis predicted.

\section{Conclusions}

By using regression moderating, the results of this study found that IFRS convergence has significant negative effect on earnings management. In addition, corporate governance mechanism, as measured by the proportion of woman in audit committee has significant negative effect on earnings management. The higher the proportion of woman in audit 
committee would reduce earnings management. However, this study found that interaction between IFRS convergence and proportion of woman in audit commmitte has positive effect on earning management.The findings of the study on the interaction of the two independent variables do not fit with the theory and it shows the need for further research.

\section{References}

1. L. Cai, A. Rahman, S. Courtenay, Available at: http://ssrn.com/abstract=1473571 (2008)

2. S. Callao, J. I. Jarne, Account. Eur. 7, 159-189 (2010)

3. V. Capkun, A. Cazavan-jeny, T. Jeanjean, L. A. Weiss, Available http//ssrn.com/abstract=1125716 1, pp. 1-63 (2011)

4. D. Zéghal, S. Chtourou, Y. M. Sellami, J. Int. Account. , Audit. Tax. 20, 61-72 (2011)

5. R. N. Qomariah, Thesis Diponegoro University Semarang Indonesia, (2013).

6. Y. O. Lestari, El Muhasaba J. Akunt. 2 (2013)

7. Y. P. Handayani, Thesis Universitas Negeri Padang (2014)

8. P. Iranto, Thesis Diponegoro University Semarang Indonesia (2014)

9. A. D. Nastiti, Thesis Diponegoro University Semarang Indonesia (2015)

10. M. C. Jensen, W. H. Meckling, J. financ. econ. 3, 305-360 (1976)

11. P. M. Healy, J. M. Wahlen, Account. Horizons 13, 365-383 (1999)

12. T. Jeanjean, H. Stolowy, J. Account. Public Policy 27, 480-494 (2008)

13. C. Liu, L. J. Yao, N. Hu, L. Liu, J. Accounting, Audit. Financ. 26, 659-676 (2011)

14. A. Klein, J. Account. Econ. 33, 375-400 (2002)

15. J. Bédard, S. M. Chtourou, L. Courteau, Audit. A J. Pract. Theory 23, 13-35 (2004)

16. A. Marra, P. Mazzola, A. Prencipe, Int. J. Account. 46, 205-230 (2011).

17. R. Jao, G. Pagalung, J. Akunt. Audit. 8, 43-54 (2011)

18. D. A. Carter, B. J. Simkins, W. G. Simpson, Financ. Rev. 38, 33-53 (2003).

19. M. Huse, A. G. Solberg, Woman Manag. Rev. 21,113-130 (2006)

20. D. Jamali, A. Safieddine, M. Daouk, Corp. Gov. 7, 574-585 (2007)

21. R. B. Adams, Daniel Ferreira, J. financ. econ. 94, 291-309 (2009)

22. I. P. Nuratama, Thesis Udayana University Denpasar Indonesia (2011)

23. Y. Chen, Z. Rezaee, Int. J. Account. Inf. Manag. 20, 171-188 (2012)

24. W. A. W. Ismail, K. A. Kamarudin, T. van Zijl, K. Dunstan, Asian Rev. Account. 21, 53-73 (2013) 